\title{
FORMATION OF A RESPECTIVE ATTITUDE IN CHILDREN OF 5 YEARS OLD TO ADULTS WITH THE UKRAINIAN TALES
}

\section{Antonina Karnaukhova ${ }^{1}$}

DOI: https://doi.org/10.30525/978-9934-588-53-2-15

Abstract. The problems of moral education over the last decades have been especially aggravated against the background of the implementation of modern priorities for the education of an independent personality capable of self-realization in a changing society. At the same time, in the context of the global ecological and spiritual crisis, the problem of human coexistence becomes more and more important as a spiritual imperative to preserve life on earth. The pedagogical and psychological researches are analyzed and the essence of the concept of «respectful attitude» in relation to children of 5 years old is specified; the components, criteria, indicators and the levels of respect of the children of 5 years old to adults are defined. A schematic model of the methodology of forming a respectful attitude in children of 5 years old to adults is substantiated, and its effectiveness in the educational process of pre-school establishments of Ukraine is tested. Methods and conducting of experimental work are described; the results of the experiment are presented. The data obtained indicate the effectiveness of the method of forming a respectful attitude in children of 5 years old to adults by means of the Ukrainian fairy tale. The prospect of further research requires the issue of the educational trajectory of educators in order to enhance their pedagogical competence in moral education.

\section{Introduction}

In modern society, socio-cultural processes are taking place that actively influence the style of human relationships, models of interpersonal interaction, penetrate even into the sphere of relationships between preschool children and adults (parents, educators and other close adults).

\footnotetext{
${ }^{1}$ Candidate of Pedagogical Sciences,

Senior Lecturer at the Department of Pedagogy and Psychology,

Pedagogical Institute

Boris Grinchenko University of Kyiv, Ukraine
} 
When creating a family microclimate, parents form in children value orientations and moral norms in children, bring up socially significant personal qualities in them and gradually involve them in public life. Therefore, the family needs pedagogical support from the first educational institution - a preschool institution, in particular from a preschool teacher.

Studying the problems of moral education, scientists distinguish the concept of «honors», which define one of the most important qualities of personality (A. Arkhangelsky, O. Drobnitsky, I. Kon). Due to the fact that the modern family is undergoing a transformation of intergenerational relationships (M. Mead), the issue of developing a respectful attitude in children of 5 years old to adults is of particular importance. In addition, age characteristics indicate a special sensitivity of this period for such upbringing (L. Artemova, G. Belenka, N. Gavrish, I. Karabaeva, O. Kononko, V. Kuzmenko, M. Mashovets, T. Pirozhenko, T. Ponymanskaya ).

The problem of forming a respectful attitude of children to adults in philosophical, psychological, pedagogical aspects was considered by scholars of the past and present (J. Komensky, D. Lokk, J. Pestalozzi, S. Rusova, V. Suhomlinsky, K. Ushinskiy). In particular, the scientists analyzed the role of communication in the personal development of preschoolers (D. Elkonin, O. Kononko, V. Kuzmenko, M. Lisina, E. Subotsky); peculiarities of formation of value attitude towards peers at preschool age (T. Ponymanskaya, Y. Prykhodko); influence of social emotions on interaction of preschool children (O. Zaporozhets, V. Kotyrlo, L. Strelkova); specifics of manifestation of humane relations of preschool children in joint activity (L. Artemova, A. Goncharenko, O. Smirnova); issues of holistic upbringing of children in the family (T. Alekseenko, L. Gurash, M. Mashovets); preparation of future caregivers for the formation of respectful attitude in children of preschool age to adults (O. Butenko, O. Kozlyuk, A. Kurchatova).

The study of the philosophical and historical aspects of the problem of the cultivation of respectful treatment of adults allows us to conclude that this problem has been and is extremely urgent in the theory and practice of philosophy and pedagogy, which is the reason for the tendency to deepen the scientific search for its solution in modern society.

The purpose of the study has been to theoretically substantiate and experimentally test the effectiveness of pedagogical conditions of forming 
a respectful attitude in children of 5 years of age to adults by means of the Ukrainian fairy tale.

Objectives of the study:

1. To clarify the essence of the key concept of «respectful attitude» towards children of 5 years old on the basis of theoretical analysis.

2. Identify the components, criteria, indicators and characterize the levels of respect for children of 5 years old to adults.

3. To develop and experimentally test the method of forming respectful attitude in children of 5 years of life to adults by means of Ukrainian fairy tale.

Theoretical and methodological bases of the study are: personally oriented and active approaches to education; theoretical provisions on personality development and humanization of education and upbringing; philosophical and psychological-pedagogical ideas about the nature of the values of personality; conceptual ideas about moral education, including preschool children; psychological and pedagogical research of mechanisms of interpersonal communication and partnership relations; research into the specifics of the development of preschool language and the role of fiction in the education of preschool children; work on the pedagogical potential of folklore, including the introduction of the Ukrainian fairy tale in the educational process.

The research is based on the principles of systematic, scientific, creative approach to the individual as a subject of the educational process. The scientific novelty of this study is that for the first time pedagogical conditions (creation of a development environment in a preschool educational institution in order to provide a positive emotional background to the students' moral content of fairy tales; systematic enrichment of the knowledge of children of 5 years old by the content of fairy tales; involvement of children in practically oriented activities in the context of creative interpretation of fairy tales with subsequent behavioral projection); components (cognitive, emotional, behavioral) are separated.

Thus, the study of the problem of forming a respectful attitude towards adults shows that this problem has been and is extremely urgent in the theory and practice of psychology and pedagogy, which is the reason for the tendency to deepen the scientific search for its solution in modern society. 


\section{The essence of the concept of «respectful attitude»}

Analysis of scientific sources in the field of philosophy makes it possible to state that the problem of moral education was the subject of study of many representatives of the ancient school of philosophy. In particular, Confucius, whose moral concept was based on the doctrine of philanthropy, was the expression of the morality of ancient Chinese philosophy. The essence of this morality was to settle relationships between people from cities, states, that often did not know each other but whose interests were the same.

Theoretical and conceptual substantiation of the autonomy of «morals», first implemented by I. Kant, related to the increase of authority and influence as a special way of normative regulation, the extension of moral evaluation and self-esteem in various spheres of human life. Due to socio-cultural dynamics, certain moral values become determinative or lose their weight. In modern ethics, the quest for the embodiment of intersubjective universal meanings necessitates the search for absolute, unmistakable ethical maxims. The effectiveness of modern strategies of social development depends on the personal factor and universal, which takes into account the globalplanetary dimension of modern civilization processes.

Using the philosophical encyclopedic dictionary, we define the concept of «moral values»:

- comprehended by moral consciousness, ethically substantiated due virtues and appropriate standards of behavior (wisdom, courage, tolerance, loyalty, truthfulness, sincerity);

- generalized content of basic ethical concepts (good and evil, justice, happiness, dignity, honor, obligation, etc.) and principles (altruism, humanism, reverence for life);

- universal connections, demands, ideals of morality, which have independent status, are directly relevant to man, approved by public opinion, embodied in law, religion, art, philosophy [18, p. 357].

Summarizing the position of the philosophical theory of morality, we note that the result of theoretical judgments is the implementation of the categorical apparatus of the phenomenon under study in the formation of personality from preschool childhood, which manifests itself in relation to society in general and to adults in particular. Valuable attitudes towards a person (adult, child) are based on the concepts of «value» and «value 
orientation» (V. Blumkin, O. Drobnitsky, V. Tugarinov). Valuable attitude towards the person around the world belongs to the moral category.

According to I. Beh, value attitudes include a sense of the value of another person, his or her moral identity. The scientist emphasizes that adults "are obliged to assist the child in observing his or her social norms, but not in the form of categorical imperatives, but by explaining to him or her the functional elementary rules that operate in the society of the people among whom she lives" [3, p. 152]. That is why the study of the problem of the formation of respectful attitude towards adults in the world scientific literature testifies to its relevance and priority role in observing the important laws of the spiritual development of society.

One of the most important value categories in the field of moral education is a respectful attitude based on the moral value concept of "honor". Solving the problem of research is primarily related to the definition of this conceptual term, which is not interpreted in the Pedagogical and Psychological Dictionaries, and the Pedagogical Encyclopedia [15, pp. 315, 317]. Thus, in Large Explanatory Dictionary of the Modern Ukrainian Language, the concept of «reverence» is interpreted as «a sense of respect based on the recognition of great virtues, public weight or positive qualities of someone - anything; an outward display of a sense of respect for honor to anyone - anything; showing respect, honoring someone» [7, p. 586]. The concept of «respect» is interpreted as «a sense of reverence, a favorable attitude based on the recognition of someone's merit, high positive qualities, someone, something» [7, p. 587], that is, these two concepts are interdependent. A similar interpretation is defined in the Ethics Dictionary «respect, respectful attitude based on recognition of one's merits» [16, p. 271]. A thorough definition of the concept of «respect» is given in the Dictionary of the Ukrainian Language, where it is considered as one of the most important requirements of morality, which presupposes such relations between people, in which the dignity of the individual is recognized in the corresponding actions, motives and social conditions of society. The notion of respect that developed in the moral consciousness of mankind implies: «justice, equality of rights, opportunity, fuller satisfaction of the interests of people, ... trust in people, attentive attitude to their beliefs, goals; responsiveness, courtesy, delicacy, modesty...» [17, p. 215]. 
The analysis of scientific sources made it possible to point out that the content of the concepts of «honor» and «respectful attitude» in its interpretation is based on such definitions as respect, love, reverence, trust, etc. Thus, the analysis of the above concepts allowed to state that in the statements mentioned the essence of the term "respect" is regarded as a norm of social morality, which is a requirement for each individual, involves only humane relations between people, recognition of the dignity of each person. In interpretive sources, «respect» is seen as a practical component in relation to others, based on the ability to bring their own attitude to the individual, meet his needs. At the same time, true respect is opposed not only by contempt, humiliation, indifference, cynicism, self-centeredness, but also false, perverted types of respect - indulgence, conformism, flattery, as well as pity and envy. The organic unity of such personality traits as the expression of concern, courtesy, obedience, kindness, empathy with others has been reflected in the concept of «respectful attitude».

Based on the above, we have come to the conclusion that a respectful attitude is a manifestation of respect based on individual moral virtues or personality traits. In our further study, we will use the definition of "respect", "respectful attitude", defining that the concept of "honor" is synonymous with the concept of "respect".

Thus, the study of philosophical, sociological, psychological and pedagogical researches and their analysis made it possible to note that throughout the history of human development and formation for the solution of the problem of relations "adults and children", no single universal recipe has been found, but every philosopher, scientist and the average person thought more than once about this question and everyone in his or her own way has tried to find ways to solve it.

\section{The content of the method of forming a respectful attitude of children of 5 years old to adults}

The analysis of the results of the scientific search of different authors (I. Beh, N. Gavrish, O. Kononko, T. Ponymanskaya, O. Reypolska) created the preconditions for expressiveness of ideas about their own research problem and provide solutions to our problems, taking into account scientifically proven facts that determines the firmness of the rationale for 
their own judgments and the reasonableness of constructing a schematic model of the method of forming a respectful attitude in children of 5 years old to adults by means of the Ukrainian fairy tale.

In the practice of teachers united by the ideas of «pedagogy of cooperation» (Sh. Amonashvili, E. Ilyin, V. Karakovsky, M. Shchetinin, $\mathrm{V}$. Shatalov), new approaches to the upbringing of the younger generation have emerged, alternative to the normative approach so far, which has led to the gradual transition of moral education from the socially oriented to the personality-oriented. In recent years, this model of child-rearing has become more widespread (I. Beh, O. Bohinich, E. Bondarevskaya, N. Gavrish, O. Kononko, T. Ponymanskaya, O. Savchenko, O. Sukhomlinskaya, and I. Rogalskaya). In the field of preschool education, a person-centered approach was the basis of the Basic Component of Preschool Education in Ukraine (2012) and the Basic Program for the Development of Pre-school Child "I am in the World" (2014) [2; 9]. Therefore, the methodological basis is a person-oriented theoretical approach to the organization of the process of forming a respectful attitude in children of 5 years old to adults, based on the principles of self-esteem, a deep respect and empathy for her, taking into account her personality.

The main principle of organizing the educational work of the institution of preschool education, according to the provisions of I. Beh, should be the principle of child-centrism, which recognizes the priority of the child's personality as a subject of education. The whole educational process should aim at "the formation of a harmonious, comprehensively developed, lifecompetent, unique personality, able to value the nature, the subject world, people, himself and his life" $[3$, p. 6]. Focusing on the outlined theoretical approach to the organization of the process of forming a respectful attitude in children of 5 years old to adults, the basis of the initial study is based on a number of initial principles of functioning of the personality-oriented approach to education:

- humanization and democratization of education - creating conditions for the formation of a respectful personality, humanizing relationships between adults and children, respect for the child's personality; the elimination of the authoritarian style of education, the attitude to the child's personality as the highest value, the rejection of teachers and adults of any violent forms of physical and psychological influence on 
the process of forming a respectful attitude in children of 5 years old to adults [3, p. 96];

- differentiation and individualization of the educational process taking into account in the process of forming a respectful attitude to the adult levels of its physical, mental, social, spiritual, intellectual development, stimulating the activity of the child, revealing his creative personality [3, p. 96];

- nature of upbringing - taking into account in the education of the senior preschoolers respect for adults the holistic nature of the child, his age, individual, national characteristics;

- continuity and consistency - implies continuity and consistency in the implementation of the stages of work on the formation of respectful attitude in children of 5 years of life to adults;

- integration - ensuring the unity of purpose, tasks, pedagogical requirements of preschool educational institution and family in the process of forming respectful attitude in children of 5 years of life to adults; providing pedagogical education for parents; raising the effectiveness of the process of forming a respectful attitude in children of the 5th year of life with adults through joint efforts of teachers and adults;

- integrity - the formation of a respectful attitude in children of 5 years old to adults is organized as a holistic pedagogical process, aimed at forming a holistic picture of the modern social world and determining the place of the child in it; covers all spheres of life of a child in a preschool educational institution and is carried out in educational activities in all social institutions (preschool educational institution, in the family, in the public), provided that their influence is integrated [3, p. 21];

- purposeful creation of emotionally enriched educational situations creating an educational situation that triggers the emotional experiences of the child and prompts action [3, p. 123];

- empathy - to teach the child to distinguish between the emotions of the adult, by linking them to their condition and behavior; the formation of an emotional experience in the child, which will act as a moral property, which will regulate its behavior towards the adult [3, p. 27];

- the principle of analyzing one's own and other's actions - giving the child the opportunity to make an independent decision in a play situation, having made a choice between several variants of behavior [3, p. 27]. 
Thus, the above theoretical provisions have become the starting point in substantiating the model and developing a methodology for the implementation of pedagogical conditions for the formation of respectful attitude in children of 5 years old to adults by means of the Ukrainian fairy tale. In developing a model for the formation of respectful treatment of children of 5 years old with adults, the Ukrainian fairy tale is based on the fact that the main task of preschool education is to preserve and strengthen the physical, mental and spiritual health of the child. Such moral qualities as kindness, compassion, help, honor, respect, charity, and the ability to use modern forms and methods of working with children of preschool age should be inherently adults. The result will be the formation of a respectful attitude in children of 5 years old to adults by means of the Ukrainian fairy tale.

The developed methodology is based on the components, criteria and consists of the purpose, pedagogical conditions, stages and result, which are components of the defined scheme. We began to develop the methodology with the goal definition, and we were guided by the results of the theoretical analysis presented in the first section of the paper and the ascertaining stage of the study. The methodology identifies three structural components: cognitive, emotional, and behavioral.

Another component of the scheme of forming a respectful attitude in children of 5 years old to adults is pedagogical conditions.

Thus, in our opinion, the process of forming a respectful attitude in children of 5 years old to adults will significantly improve during the implementation of the following pedagogical conditions: creation of a development environment in the preschool education institution in order to provide a positive emotional background for the students' perception of the moral content of fairy tales; systematic enrichment of knowledge of children of 5 years old with the content of fairy tales of moral orientation; involvement of children in practically oriented activities in the context of creative interpretation of fairy tales with subsequent behavioral projection.

During the implementation of pedagogical conditions in all areas of work, to develop a respectful attitude in children of 5 years of life to adults, the following methods were used: traditional (demonstrations, explanations), interactive (engaging in dialogue, reproductive), creative and stimulating 
(stimulating to practical search activities), which were specific to the target recipient (children, parents, educators).

Thus, under the model of formation of respectful attitude in children of 5 years old to adults we understand the schematic, descriptive characteristic of the author's methodology, which contains the following components: purpose, components, criteria, pedagogical conditions, stages and their tasks, the result, which is shown in Figure 1.

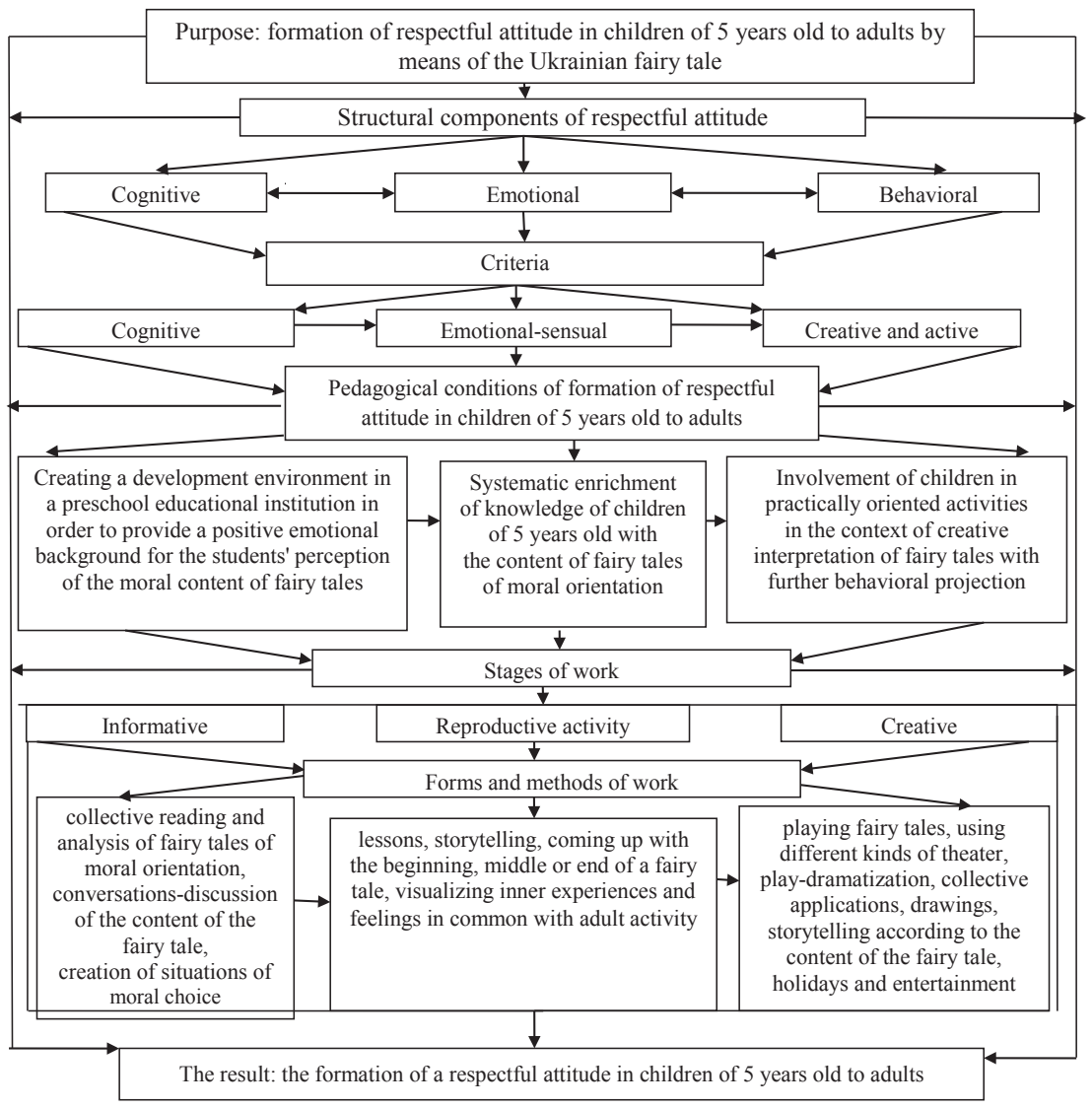
Figure 1. The scheme of formation of respectful attitude in children of 5 years old to adults by means of the Ukrainian fairy tale




\section{Organization and carrying out of experimental work}

The purpose of the experimental study was to develop and experimentally test methods of realization of pedagogical conditions for the formation of respectful attitude in children of the 5th year of life to adults by means of the Ukrainian fairy tale. Three experiment cycles were conducted: during 2013-2017, 2014-2018, 2015-2019 on the basis of pre-school educational establishments in Kyiv, Kamianets-Podilskyi, Khmelnytskyi region and Malyn, Zhytomyr region. At different stages of the study, 185 children of 5 years old were enrolled (92 in the experimental and 93 in the control group). Within the framework of the experiment, the schematic model described above was developed and implemented, the content of which was based on components, criteria and consists of the goal, pedagogical conditions, stages and results.

The experiment involved the fulfillment of a set of tasks, namely: to determine the levels of formation of respectful attitude in children of 5 years old to adults; to expand, clarify, reinforce children's knowledge of the essence of the concept of «respectful attitude» to adults, to give an idea of the components of this moral norm, the relevant moral and ethical standards of behavior and communication with adults; to develop the ability to show respect for and interact with adults.

Based on psychological and pedagogical provisions (I. Karabaeva, O. Kononko, V. Kuzmenko, T. Pirozhenko), the components of a respectful relationship with adults were distinguished components that were interconnected and complementary: information (mastery of ideas and knowledge of respect for adults); emotional (positive attitude to the content and manifestations of respectful attitude towards adults and understanding of its motives); behavioral (ability to show respect for adults in actions).

This was the basis for determining the criteria and indicators: cognitive (understanding the concept of «respectful attitude»; independence of awareness of the inner state of loved ones; the ability to show respectful attitude to adults; the ability to consciously concede to their desires); emotional and sensory (the ability to identify and adequately respond to the feelings and emotions of adults; the ability to feel and understand the emotional state of adults and the reasons that can cause it; to treat adults as values; the ability to empathize); creative activity (the ability to give a reasoned assessment of actions against adults; the ability to provide 
unselfish assistance to adults in everyday life; the ability to find the right way out of a situation involving moral action against adults independently; the ability to creatively interpret the moral content of the tales of the tales; levels of respectful attitude in children of 5 years of age to adults: low, medium, sufficient, high.

Thus, the methodology of the experimental work consisted in the selection and realization of the tasks of studying the levels of the formation of respectful attitude in children of 5 years of life to adults by means of the Ukrainian fairy tale, and comparing the results in order to establish the dynamics of shifts by certain criteria and indicators.

\section{The results of the experiment}

According to the results of the ascertainment experiment, in particular, the information component revealed a high level of $1.80 \%$ of EG children and $2.15 \%$ of CG children; sufficient - in $3.26 \%$ of EG children and $4.30 \%$ of CG children; average - in $26.08 \%$ of EG children and in $25.80 \%$ of children of CG; low - in $69.56 \%$ of EG children and in $67.74 \%$ of CG children. A high level of emotional component was not detected; sufficient in $7.60 \%$ of EC children and $10.75 \%$ of CG children; average - in $23.91 \%$ of EG children and in $22.58 \%$ of CG children; the low level of respectful attitude in children of 5 years old to adults was found in $68.47 \%$ of EG children and $66.66 \%$ of CG children. By the behavioral component, a high level was detected in $3.26 \%$ of EG children and $3.22 \%$ of CG children; sufficient - in $4.34 \%$ of EG children and $7.52 \%$ of CG children; the average - in $25.00 \%$ of CG children and in $23.65 \%$ of CG; low $-67.39 \%$ of EG children and $65.59 \%$ of CG children are shown in Table 1.

The purpose of the experimental stage of the work was to experimentally test the method of forming a respectful attitude in children of 5 years old to adults by means of the Ukrainian fairy tale. The methodology involved the realization of pedagogical conditions: creation of a development environment in the preschool education institution in order to provide a positive emotional background for the students' perception of the moral content of the tales; systematic enrichment of knowledge of children of 5 years old with the content of fairy tales of moral orientation; involvement of children in practically oriented activities in the context of creative interpretation of fairy tales with subsequent behavioral projection. 


\section{Comparison of levels of respectful formation in adult and control adults of 5 year olds}

\begin{tabular}{|c|c|c|c|c|}
\hline \multirow{3}{*}{$\begin{array}{l}\text { Levels of respect for } \\
\text { children of } 5 \text { years } \\
\text { of age for adults }\end{array}$} & \multirow{2}{*}{\multicolumn{2}{|c|}{$\begin{array}{c}\text { Experimental group } \\
92 \text { children }\end{array}$}} & \multirow{2}{*}{\multicolumn{2}{|c|}{$\begin{array}{c}\text { Control group } \\
93 \text { children }\end{array}$}} \\
\hline & & & & \\
\hline & $\begin{array}{c}\text { Number of } \\
\text { responses }\end{array}$ & $\%$ & $\begin{array}{c}\text { Number of } \\
\text { responses }\end{array}$ & $\%$ \\
\hline \multicolumn{5}{|c|}{ Cognitive component } \\
\hline High & 1 & 1.08 & 2 & 2.15 \\
\hline Sufficient & 3 & 3.26 & 4 & 4.30 \\
\hline Average & 24 & 26.08 & 24 & 25.80 \\
\hline Low & 64 & 69.56 & 63 & 67.74 \\
\hline \multicolumn{5}{|c|}{ Emotional component } \\
\hline High & 0 & 0 & 0 & 0 \\
\hline Sufficient & 7 & 7.60 & 10 & 10.75 \\
\hline Average & 22 & 23.91 & 21 & 22.58 \\
\hline Low & 63 & 68.47 & 62 & 66.66 \\
\hline \multicolumn{5}{|c|}{ Behavioral component } \\
\hline High & 3 & 3.26 & 3 & 3.22 \\
\hline Sufficient & 4 & 4.34 & 7 & 7.52 \\
\hline Average & 23 & 25 & 22 & 23.65 \\
\hline Low & 62 & 67.39 & 61 & 65.59 \\
\hline
\end{tabular}

As a result of the introduction of pedagogical conditions, which were implemented in stages using the developed method of forming a respectful attitude in children of 5 years old to adults by means of the Ukrainian fairy tale, positive changes in the levels of formation of respectful attitude in children of 5 years old towards adults were reported, according to information and behavioral components.

Analysis of the data obtained from the control experiment allows us to construct a table to compare the levels of self-esteem in children of 5 years old to adults in the experimental and control groups are shown in Table 2.

Therefore, the comparison of quantitative data after the completion of the molding experiment revealed a significant difference in the results of the experimental and control groups. In the experimental group, children of 5 years old have higher scores on all components of respectful attitude: the quantitative manifestation of the high level of the information component is 


\section{Comparison of levels of respectful formation in adult and control adults of 5 year olds}

\begin{tabular}{|c|c|c|c|c|}
\hline \multirow{3}{*}{$\begin{array}{l}\text { Levels of respect for } \\
\text { children of } 5 \text { years } \\
\text { of age for adults }\end{array}$} & \multirow{2}{*}{\multicolumn{2}{|c|}{$\begin{array}{c}\text { Experimental group } \\
92 \text { children }\end{array}$}} & \multirow{2}{*}{\multicolumn{2}{|c|}{$\begin{array}{c}\text { Control group } \\
93 \text { children }\end{array}$}} \\
\hline & & & & \\
\hline & $\begin{array}{c}\text { Number of } \\
\text { responses }\end{array}$ & $\%$ & $\begin{array}{c}\text { Number of } \\
\text { responses }\end{array}$ & $\%$ \\
\hline \multicolumn{5}{|c|}{ Cognitive component } \\
\hline High & 10 & 10.86 & 3 & 3.22 \\
\hline Sufficient & 67 & 72.82 & 27 & 29.03 \\
\hline Average & 12 & 13.04 & 51 & 54.83 \\
\hline Low & 3 & 3.26 & 12 & 12.90 \\
\hline \multicolumn{5}{|c|}{ Emotional component } \\
\hline High & 9 & 9.78 & 4 & 4.30 \\
\hline Sufficient & 65 & 70.65 & 28 & 30.10 \\
\hline Average & 14 & 15.21 & 48 & 51.61 \\
\hline Low & 4 & 4.34 & 13 & 13.97 \\
\hline \multicolumn{5}{|c|}{ Behavioral component } \\
\hline High & 9 & 9.78 & 2 & 2.15 \\
\hline Sufficient & 62 & 67.39 & 26 & $2 ., 95$ \\
\hline Average & 15 & 16.30 & 54 & 58.06 \\
\hline Low & 6 & 6.52 & 11 & 1182 \\
\hline
\end{tabular}

higher in the experimental group by $7.64 \%$ compared to the control group; emotional - by $5.48 \%$; behavioral - by $7.63 \%$.

\section{Conclusions}

The results of theoretical and experimental research have led to the formulation of the following conclusions:

1. Theoretical analysis of the formation of respectful attitude in children of 5 years old to adults has shown that the problem under study, which has long troubled philosophers, educators, psychologists, has not lost its relevance. Any relationship is a complex formation, in which actions realize knowledge, motives, feelings, emotions, interests of the subject to the subject.

The concept of «respectful attitude» towards children of 5 years old has been clarified as an expression of respect based on the individual's moral virtues or qualities of the person to whom this attitude is expressed. Given 
the age characteristics of children of 5 years old, the concept of «respectful attitude» is associated with manifestations in children of such qualities as: concern, politeness, obedience, kindness, empathy.

2. Components of respectful attitude are cognitive, emotional, behavioral. Accordingly, the criteria and indicators of the formation of the studied quality in children of 5 years old are defined: cognitive (understanding of the concept of «respectful attitude»; independence of awareness of the inner state of loved ones; the ability to show respectful attitude to adults; the ability to consciously concede to their desires); emotional and sensual (the ability to identify and adequately respond to the feelings and emotions of adults; the ability to feel and understand the emotional state of adults and the reasons that can cause it; to treat adults as values; the ability to empathize and empathize); creative and active (the ability to give a reasoned assessment of actions against adults; the ability to provide unselfish help to adults in everyday life; the ability to find the right way out of a situation involving moral action against adults independently; the ability to creatively interpret the moral content of the tales of projection). Based on the above components, criteria and indicators, the levels of respectful attitudes in children of 5 years old to adults (high, sufficient, medium, low) are characterized. The pedagogical conditions of formation of respectful attitude of children of 5 years old to adults by means of the Ukrainian fairy tale are revealed, namely: creation of development environment in preschool educational institution with the purpose of providing a positive emotional background of the students' perception of the moral content of fairy tales; systematic enrichment of knowledge of children of 5 years old with the content of fairy tales of moral orientation; involvement of children in practically oriented activities in the context of creative interpretation of fairy tales with subsequent behavioral projection.

3. Methods of forming respectful attitude of children of 5 years old to adults by means of Ukrainian fairy tale have been developed and experimentally tested.

Further scientific studies need questions on the educational trajectory of educators in order to improve their pedagogical competence in the problems of moral education and to introduce into the system of pedagogical education of special courses, seminars, workshops for moral education of preschool children. 


\section{References:}

1. Artemova, L. V. (1992). Okruzhaiushchyi myr v dydaktycheskykh yhrakh doshkolnykov [The world around in didactic games of preschoolers]. Moscow: Prosveschenie, $96 \mathrm{p}$.

2. Bazovyi komponent doshkilnoi osvity (2012). [Basic component of preschool education]. Preschool education, no. 1. pp. 6-9.

3. Bekh, I. D. (2003). Vykhovannia osobystosti. Osobystisno oriientovanyi pidkhid: Teoretyko-tekhnolohichni zasady [Personal education. Personally oriented approach: Theoretical and technological principles]. Kyiv: Lybid, $280 \mathrm{p}$.

4. Bekh, I. D. (2008). Vykhovannia osobystosti [Personal education]. Kyiv: Lybid, 848 p.

5. Bekh, I. D. (1991). Vidchuttia provyny v moralnomu rozvytku osobystosti [The feeling of guilt in the moral development of the individual]. The Soviet School, no. 4 , pp. 37-42.

6. Bielienka, H. V. (2004). Navchannia cherez kazku [Learning through a fairy tale]. Preschool education, no. 1, pp. 14-17.

7. Velykyi suchasnyi slovnyk suchasnoi ukrainskoi movy (2005). [Great modern dictionary of modern Ukrainian]. Kyiv: Irpen: VTF «Perun». 1728 p.

8. Honcharenko, S. U. (1997). Ukrainskyi pedahohichnyi slovnyk [Ukrainian Pedagogical Dictionary]. Kyiv: Lybid, 376 p.

9. Kononko, O. L. Prohrama rozvytku dytyny doshkilnoho viku «Ia u Sviti» (2014). [Pre-school Child Development Program «I'm in the World»]. Kyiv: MCFER-Ukraine, $452 \mathrm{p}$.

10. Krutii, K. L. (2008). Predmetno-rozvyvalne seredovyshche yak chynnyk suprovodu diialnosti ditei [Objective and developmental environment as a factor of support of children's activity]. Preschool education, no. 2(20), pp. 9-20.

11. Mashovets, M. A. (2010). Batky ne prodaiutsia [Parents are not for sale] Rodynne vykhovannia: suchasni pidkhody [Family education: current approaches]. Kyiv: School World, 6-10 pp.

12. Ponimanska, T. I. (2008). Vykhovannia liudianosti [Education of humanity]. Kyiv: Millennium, $136 \mathrm{p}$.

13. Reipolska, O. D. (2013). Formuiemo u starshykh doshkilnykiv tsilisne svitobachennia [Forming a holistic outlook for older preschoolers]. Kyiv: «Imex-LTD», 260 p.

14. Rohalska, I. P. (2008). Sotsializatsiia osobystosti u doshkilnomu dytynstvi: sutnist, spetsyfika, suprovid [Socialization of personality in preschool childhood: essence, specificity, support]. Kyiv: Millennium, 400 p.

15. Volovnykova, H. M. (1960). Pedahohycheskyi slovar [Pedagogical Dictionary]. Moscow: Prosveschenie, 493 p.

16. Huseinova, A. A. (1989). Slovar po etyke [Dictionary of Ethics]. Moscow: Politizdat, $447 \mathrm{p}$.

17. Bilodid, Y. K. (1970). Slovnyk ukrainskoi movy [Dictionary of the Ukrainian language]. Kyiv: Scientific Opinion, 700 p.

18. Svidlo, M. S. (1996). Filosofiia [Philosophy]. Kyiv: KDTUBA, 468 p. 